
\title{
pombalina
}

(8)

\section{Modeling fuels and treatment effects in 3D with STANDFIRE}
Parsons, Russ; Pimont, Francois; Wells, Lucas; Cohn, Greg; Jolly, W.
Autor(es): $\quad$ Matt; Davis, Brett; Coligny, Francois de; Mell, William "Ruddy"; Rigolot, Eric; Dupuy, Jean-Luc

Publicado por: Imprensa da Universidade de Coimbra

URL persistente:

URI:http://hdl.handle.net/10316.2/44702

DOI:

DOI:https://doi.org/10.14195/978-989-26-16-506_185

Accessed : $\quad$ 26-Apr-2023 10:14:38

A navegação consulta e descarregamento dos títulos inseridos nas Bibliotecas Digitais UC Digitalis, UC Pombalina e UC Impactum, pressupõem a aceitação plena e sem reservas dos Termos e Condições de Uso destas Bibliotecas Digitais, disponíveis em https://digitalis.uc.pt/pt-pt/termos.

Conforme exposto nos referidos Termos e Condições de Uso, o descarregamento de títulos de acesso restrito requer uma licença válida de autorização devendo o utilizador aceder ao(s) documento(s) a partir de um endereço de IP da instituição detentora da supramencionada licença.

Ao utilizador é apenas permitido o descarregamento para uso pessoal, pelo que o emprego do(s) título(s) descarregado(s) para outro fim, designadamente comercial, carece de autorização do respetivo autor ou editor da obra.

Na medida em que todas as obras da UC Digitalis se encontram protegidas pelo Código do Direito de Autor e Direitos Conexos e demais legislação aplicável, toda a cópia, parcial ou total, deste documento, nos casos em que é legalmente admitida, deverá conter ou fazer-se acompanhar por este aviso.

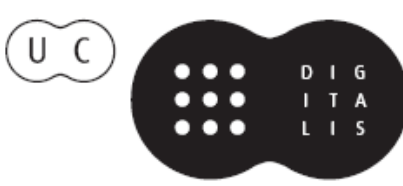




\section{ADVANCES IN}

\section{FOREST FIRE RESEARCH}

\section{8}

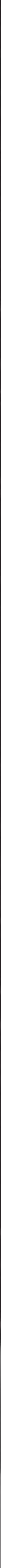


Short contribution - Decision Support Systems and Tools

\title{
Modeling fuels and treatment effects in 3D with STANDFIRE
}

\author{
Russ Parsons ${ }^{1 *}$; Francois Pimont ${ }^{2}$; Lucas Wells ${ }^{3}$; Greg Cohn ${ }^{4}$; W. Matt Jolly ${ }^{1}$; Brett Davis ${ }^{1}$; Francois de \\ Coligny"; William "Ruddy" Mell'; Rod Linn"; Eric Rigolot'; Jean-Luc Dupuy ${ }^{2}$ \\ ${ }^{I}$ USFS RMRS, Fire Sciences Lab. 5775 Highway 10 W, Missoula, MT, \{rparsons@fs.fed.us*\} \\ ${ }^{2}$ URFM INRA. 84914, France, \{francois.pimont@inra.fr\} \\ ${ }^{3}$ Department of Forest Engineering, Resources and Management, College of Forestry, Oregon State \\ University, 210 Snell Hall, Corvallis, OR 97331, USA, \{lawells36@gmail.com\} \\ ${ }^{4}$ Department of Forest Ecosystem and Society, College of Forestry, Oregon State University, 321 \\ Richardson Hall, Corvallis, OR 97331, USA, \{cohng@oregonstate.edu\} \\ ${ }^{5}$ AMAP, INRA, Cirad, CNRS, IRD, Univ Montpellier, France \{francois.decoligny@inra.fr\} \\ ${ }^{6}$ U.S. Forest Service Pacific Wildland Fire Sciences Lab, $400 \mathrm{~N} 34^{\text {th }}$. Street, Suite 201, Seattle, WA 98103, \\ USA, \{wemell@fs.fed.us\} \\ ${ }^{7}$ Environmental Sciences Division, Los Alamos National Laboratory, Mail stop: D401, Los Alamos, NM \\ 87544,USA, \{rrl@lanl.gov\}
}

\begin{abstract}
Fuel treatments offer a means of proactively mitigating risks to firefighters and communities, and to restore altered ecosystems. The cost and potential impacts associated with implementing such treatments, however, suggest a need for thorough understanding of their effectiveness before they are carried out on the ground, particularly at landscape scales. At present, modelling tools used to evaluate fuel treatments are often limited in their ability to represent fuels or fuel/fire interactions. This is particularly true for treatments that seek to modify forest spatial patterns; most modelling frameworks are not spatially explicit and thus can only describe forests in terms of overall average characteristics. Here, we describe STANDFIRE, a prototype 3D platform for modeling wildland fuels and fire behavior at stand scales. Leveraging a powerful core modeling architecture, STANDFIRE links a forest growth model to physics-based fire behavior models, providing a means by which detailed fuels data can be used as input in physics-based fire behavior simulations which can explore fuel treatment effectiveness or sensitivity to environmental conditions. We describe the model, some applications, and plans for continuing development.
\end{abstract}

Keywords: Fuel modeling, Fuel treatments, Fire behavior, Physics-based, WFDS, FIRETEC, FuelManager

\section{Introduction}

Fuel treatments such as thinning are used to alter fire behavior, mitigate risks to firefighters and communities and reduce fire severity. Many forest ecosystems have undergone significant changes in composition and structure over the last several decades (Hessburg et al 2005), often resulting in conditions that threaten their long term viability (Fulé et al 2014). Recent studies suggest that fuel treatments that create spatially heterogeneous fuel patterns can restore ecosystem resilience by creating diverse post-fire conditions (Larson and Churchill 2012). However, at present, forest modeling systems used to evaluate fuel treatments are not spatial, and employ very simple fire models that cannot accommodate fuel heterogeneity at an appropriate level of detail (Rothermel 1972). Given the scale at which ecosystem restoration and associated fuel treatments are needed, there is a substantial need for modeling that can be used to explore fuel treatment effectiveness in a spatially explicit manner. In this paper, we discuss STANDFIRE, a 3D prototype modeling platform for fuels, fire behavior and effects, that may offer new capabilities in this arena. 


\section{Model Overview}

STANDFIRE is a prototype system for spatially explicit, 3D modeling of fuels, fire behavior and effects. STANDFIRE's modular architecture links four main components (Figure 1): 1) forest growth and biomass modeling with the Forest Vegetation Simulator (FVS, Crookston and Dixon 2005) 2) a core 3D fuel modeling architecture (see below) producing fuels inputs for 3) physics-based fire behavior models WFDS (Mell et al 2009) and FIRETEC (Linn et al. 2005) and 4) post-processors that calculate fire behavior and effects results from simulation outputs. More detail regarding these components can be found in a recent publication (Parsons et al 2018).

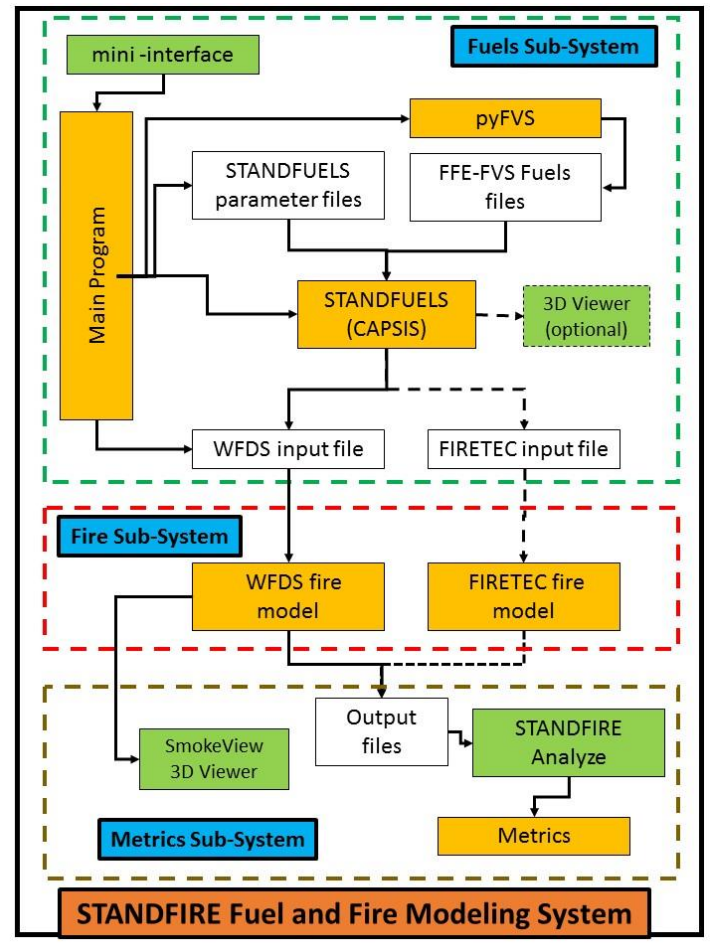

Figure 1 - Flow chart of STANDFIRE components

A particularly important component in STANDFIRE is STANDFUELS, a module of the CAPSIS platform (Dufour-Kowalski et al 2012) which provides critical capabilities for detailed but scalable fuel modeling. This module is based on the FireLib library -also used in FuelManager (Pimont et al 2016)- and models vegetation either as Plants, such as large trees or shrubs, or as LayerSets, which are irregular (user specified) polygons (Figure 2A) associated with sets of attributes and which can contain other spatially explicit entities. For example, a LayerSet could contain multiple shrub species (as separate Layers) each of different sizes and properties. These basic, but powerful building blocks provide flexibility to model nearly any kind of wildland fuel. FireLib also carries out the non-trivial numerical task of converting fuel elements with specific geometries (like a tree crown) to voxels, in a file format which serves as inputs in the physics-based models. Additional detail regarding these capabilities is provided in Pimont et al (2016).

\section{Applications}

STANDFIRE has many potential applications. The primary application that it was designed for is to facilitate more in-depth analysis of fuel treatment effectiveness. Unlike empirical or semi-empirical models which significantly abstract fuels, weather and fire, enabling rapid calculations but limiting the insights they can provide (Andrews et al., 2003, Cruz et al., 2005), physics-based fire models can model fire in situations closer to what occurs in the real world (i.e. complex topography, time and space varying ignition, and dynamic weather conditions). One of the key aspects that such models 
bring to evaluation of fuel treatments is their capacity to model fire in discontinuous and heterogeneous fuels, which are often the result (indeed, the intent) of fuel treatments (e.g. thinning). A growing body of work has examined fuel heterogeneity in a number of situations including discrete fuel beds (Linn et al., 2005), and beetle killed trees (Linn et al., 2013, Hoffman et al., 2015). Recent applications in fuel treatments highlight the importance of spatial relationships in fuels (Linn et al., 2005, Parsons 2006, Pimont et al., 2011, Contreras et al., 2012, Parsons et al., 2017, Ziegler et al., 2017). While much more work is needed, the successes of these efforts so far justify continued exploration of fuel treatments with systems such as STANDFIRE.

STANDFIRE's use of FVS for forest growth and biomass enables simulations for most forest types in the U.S. Fuel treatment effectiveness assessments are carried out through fire simulations with physics-based fire models, and through subsequent calculations of fuel and fire behavior metrics. Figure 2B shows fire behavior at the same point in time for an untreated forest (Fig. 2B upper left) and three different crown space thinning treatments. Surface fire spread rates increased with increasing levels of thinning due to reduced canopy drag effects on the wind field.

\section{Ongoing Development}
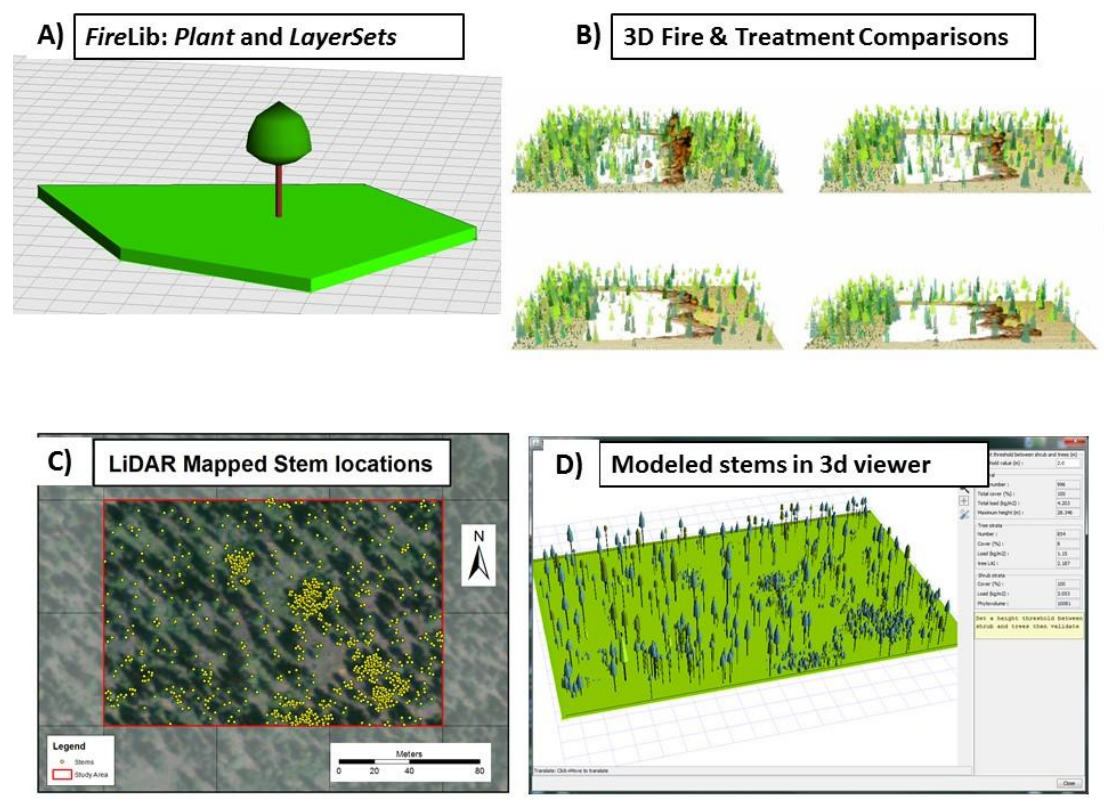

Figure 2 - Various aspects of STANDFIRE: A) example Plant and LayerSet fuel modeling approaches, B) example fire behavior comparison of different fuel treatments, C) example LiDAR mapped forest data D) example LiDAR mapped forest, as modeled fuels in STANDFIRE's $3 D$ viewer

In addition to application in fuel treatment analysis, development is currently underway to expand STANDFIRE to facilitate simulation of prescribed fires. Current efforts are focused on expanding capabilities to read in real world fuels data such as from airborne LiDAR (Figure 2C, D). At present this import is carried out through a spatial shapefile derived from LiDAR point clouds rather directly through the point cloud itself. As LiDAR data become more available, and improved approaches for automated data processing are developed (Cabo et al., 2018), the capacity to rapidly develop very detailed 3D fuels inputs will be increasingly useful. Other ongoing development includes import of different raster datasets including topography, as well as spatial and temporal data associated with real world fires, such as ignition GPS tracks and wind data. These new features will expand STANDFIRE's capabilities to rapidly develop input datasets for physics-based fire behavior models for simulations of prescribed fires, providing new capabilities for training and for examination of numerous factors that can affect prescribed fire outcomes, including fuel conditions, ignition patterns, and sensitivity to 
weather conditions, among others. These developments will also facilitate efforts to evaluate fire models with real world fire data, a key objective of several large scale fire data collection efforts in recent years.

\section{References}

Andrews PL, Bevins CD, and Seli RC (2003). BehavePlus fire modeling system, version 2.0: user's guide. USDA For Serv. Gen. Tech. Rep. RMRS-GTR-106WWW

Cabo C, Ordóñez C, López-Sánchez CA and Armesto J (2018) Automatic dendrometry: Tree detection, tree height and diameter estimation using terrestrial laser scanning. International Journal of Applied Earth Observation and Geoinformation, 69, 164-174.

Contreras MA, Parsons RA and Chung W (2012) Modeling tree-level fuel connectivity to evaluate the effectiveness of thinning treatments for reducing crown fire potential. Forest Ecology and Management, 264, 134-149.

Crookston NL, Dixon GE (2005) The forest vegetation simulator: a review of its structure, content, and applications. Comput Electron Agric 49, 60-80.

Cruz MG, Alexander ME and Wakimoto RH (2005) Development and testing of models for predicting crown fire rate of spread in conifer forest stands. Canadian Journal of Forest Research, 35(7), 16261639.

Dufour-Kowalski S, Courbaud B, Dreyfus P, Meredieu C, De Coligny F (2012) Capsis: an open software framework and community for forest growth modelling. Ann. For. Sci. 69, 221-233.

Fule' PZ, Swetnam TW, Brown PM, Falk DA, Peterson DL, Allen CD, Aplet GH, Battaglia MA, Binkley D, Farris C, Keane RE, Margolis EQ, Grissino-Mayer H, Miller C, Hull Sieg C, Skinner C, Stephens CL, Taylor A (2014) Unsupported inferences of high severity fire in historical western United States dry forests: response to Williams and Baker. Global Ecology and Biogeography 23, 825-830. doi:10.1111/GEB. 12136

Hessburg PF, Agee JA, Franklin JF (2005) Dry forests and wildland fires of the Inland Northwest USA: Contrasting the landscape ecology of the pre-settlement and modern eras. For. Ecol. Manag. 211, 117-13.

Hoffman CM, Linn R, Parsons R, Sieg C, Winterkamp J (2015) Modeling spatial and temporal dynamics of wind flow and potential fire behavior following a mountain pine beetle outbreak in a lodgepole pine forest. Agricultural and Forest Meteorology 204, 79-93.

Larson AJ, Churchill D (2012) Tree spatial patterns in fire-frequent forests of western North America, including mechanisms of pattern formation and implications for designing fuel reduction and restoration treatments. Forest Ecology and Management 267, 74-92.

Linn R, Winterkamp J, Colman JJ, Edminster C, Bailey JD (2005) Modeling interactions between fire and atmosphere in discrete element fuel beds. International Journal of Wildland Fire 14, 37-48.

Linn RR, Sieg CH, Hoffman CM, Winterkamp JL and McMillin, J.D (2013) Modeling wind fields and fire propagation following bark beetle outbreaks in spatially-heterogeneous pinyon-juniper woodland fuel complexes. Agricultural and Forest Meteorology 173, 139-153.

Mell W, Maranghides A, McDermott R, Manzello SL (2009) Numerical simulation and experiments of burning douglas fir trees. Combustion and Flame 156, 2023-2041.

Parsons RA (2006) FUEL3-D: a spatially explicit fractal fuel distribution model. In 'Fuels Management - How to Measure Success: Conference Proceedings', 28-30 March 2006; Portland, OR, USA. (Eds PL Andrews, BW Butler) USDA Forest Service, Rocky Mountain Research Station, Proceedings RMRS-P-41, pp. 253-272. (Fort Collins, CO, USA) 
Parsons RA, Linn RR, Pimont F, Hoffman C, Sauer J, Winterkamp J, Sieg, CH and Jolly WM (2017) Numerical investigation of aggregated fuel spatial pattern impacts on fire behavior. Land, 6(2), 43.

Parsons RA, Pimont F, Wells L, Linn RR, Cohn G, Jolly WM, de Coligny F, Rigolot E, Dupuy J-L, Mell W, and Linn RR (2018) Modeling thinning effects on fire with STANDFIRE. Annals of Forest Science 75(1), 1-11

Pimont F, Dupuy J-L, Linn RR, Dupont S (2011) Impacts of tree canopy structure on wind flows and fire propagation simulated with FIRETEC. Annals of Forest Science 68, 523-530. doi:10.1007/s13595011-0061-7.

Pimont F, Parsons R, Rigolot E, de Coligny F, Dupuy J-L, Dreyfus P and Linn RR (2016) Modeling fuels and fire effects in 3D: Model description and applications. Environmental Modelling and Software 80, 225-244

Rothermel RC (1972) A Mathematical Model for Predicting Fire Spread in Wildland Fuels; General Technical Report INT-115; U.S. Department of Agriculture, Forest Service, Intermountain Research Station: Ogden, UT, USA

Ziegler JP, Hoffman C, Battaglia M, Mell W (2017) Spatially explicit measurements of forest structure and fire behavior following restoration treatments in dry forests. Forest Ecology and Management $386,1-12$ 